\title{
KAJIAN KRITIS TERHADAP PRAANGGAPAN \\ METAFISIS-EPISTEMOLOGIS \\ KOSMOLOGI STEPHEN HAWKING
}

\author{
Oleh: Sindung Tjahyadi \\ Fakultas Filsafat Universitas Gadjah Mada
}

\section{A. Latar Belakang}

Peningkatan peran ilmu dalam segala aspek kehidupan manusia tidak perlu disangkal lagi. Penjelasan ilmiah semakin banyak dijadikan tonggak terakhir untuk menentukan diterima atau ditolaknya suatu pemahaman tentang realitas. Dalam tahun-tahun belakangan ini pengaruh ilmu dalam mengubah masyarakat semakin kuat (Ziman, 1984:5). Gejala penguatan pengaruh ilmu tersebut semakin nyata terutama ditunjang oleh perkembangan teknologi komunikasi.

Salah satu tonggak ilmu modern setelah Einstein adalah Hawking. Bila Einstein membuka cakrawala pemahaman manusia tentang awal mula jagad raya, Hawking berjalan lebih jauh. Hawking bermaksud membangun sebuah teori yang lengkap, konsisten, dan terpadu tentang interaksi-interaksi fisika yang akan menjelaskan semua hasil pengamatan yang mungkin (Hawking,1995b: 47). Dengan teori terpadunya Hawking bermaksud menjelaskan awal dan masa depan jagad raya, bahkan mengimpikan kemajuan ilmu alam (fisika) hingga mampu meramalkan skor dari suatu pertandingan bisbol yang belum terjadi. Klaim yang ada di balik pernyataan-pernyataan tersebut adalah bahwa ilmu fisika mampu menjelaskan segala hal. Terhadap klaim yang demikian dapat diajukan pertanyaan, sebagaimana dapat pula diajukan terhadap ilmu-ilmu alamiah yang lain, yakni: Sejauh mana klaim tersebut memiliki dasar-dasar metodologis yang memadai sebagaimana yang diizinkan oleh ilmu yang bersangkutan? Apakah ilmu alam sungguh-sungguh mampu memberi penjelasan yang lengkap tentang semesta raya? Sejauh mana fallibisme dapat dijadikan sandaran bagi pembenaran teori-teori yang secara eksperimental belum teruji? Atau dalam rumusan pertanyaan yang lebih umum, dapatkah ilmu menjawab "semua" pertanyaan kita tentang keteraturan alamiah dari benda-benda? (Rescher, 1984:6). Sejauh manakah model alam semesta (universe) yang ditawarkan.Hawking dapat diterima? Ditilik dari praanggapan metafisis-epistemologisnya, di manakah posisi yang diambil Hawking dalam menjawab masalah-masalah dasar kosmologi filsafat? Sejauh mana posisi yang demikian dapat diterima?

Tulisan ini pada dasarnya merupakan kajian filosofis terhadap suatu "kosmologi ilmiah". Dengan demikian terdapat dua pendekatan yang digunakan, yakni, pertama, hampiran filsafat ilmu, terkait dengan aspek-aspek metodologis dari kosmologi ilmiah; dan kedua, hampiran kosmologi filsafat, terkait dengan evaluasi kritis atas kosmologi Hawking dalam dimensi kosmologi filsafati, terutama berkenaan dengan posisi yang diambilnya terhadap unsur hakiki pembangun realitas dan peran pengkosmos di dalamnya khususnya terkait dengan konsep ruang-waktu, prinsip determinisme, dan hukum kekekalan energi. 
Dari kajian kritis terhadap kosmologi Hawking diharapkan:

1. Mampu memberikan batas-batas teori kosmologi Hawking dari segi metodologi ilmu.

2. Mengungkap kelebihan dan kekurangan teori Hawking dalam perspektif kosmologi filsafat.

3. Mengungkap peran kosmologi ilmiah dalam pengembangan kosmologi filsafat, dan sebaliknya.

Dalam rangka mengkaji secara kritis kosmologi Hawking, berikut akan dipaparkan terlebih dahulu ruang lingkup kosmologi; pokok-pokok Kosmologi Hawking, kemudian praanggapan metafisis-epistemologis yang ada di dalamnya, dan atas dasar paparan tersebut dibahas kelebihan dan kelemahan perspektif Hawking tentang semesta realitas kosmos. Makalah ditutup dengan sebuah kesimpulan kecil.

\section{B. Ruang Lingkup Kosmologi Filsafat}

Kosmologi berasal dari kata Yunani "kosmos" dan "logos". "Kosmos" berarti susunan, atau ketersusunan yang baik. Lawannya ialah "khaos", yang berarti "kacau balau" (Bakker, 1995: 39). Sedangkan "logos" juga berarti "keteraturan", sekalipun dalam "kosmologi" lebih tepat diartikan sebagai "azas-azas rasional" ((Kattsoff, 1986:75). Dalam sejarah filsafat Barat, tercatat Phytagoras (580 - 500 SM) merupakan orang yang pertama kali memakai istilah "kosmos" sebagai terminologi filsafat. Bahkan dalam tradisi Aristotelian, penyelidikan tentang keteraturan alam disebut sebagai "fisika" (bukan dalam pengertian modern), dan filsafat Skolastik memakai nama "filsafat alami" (philosophia naturalis) untuk menyebut hal yang sama (Bakker, 1995: 40). Istilah "kosmologi" (cosmology) dipakai pertama kalioleh Christian von Wolff dalam bukunya "Discursus Praeliminaris de Philosophia in Genere" tahun 1728, dengan menempatkannya dalam skema pengetahuan filsafat sebagai cabang dari "metafisika" dan dibedakan dengan cabang-cabang metafisika yang lain seperti "ontologi", "teologi metafisik", maupun "psikologi metafisik" (Munitz, dalam Edward, ed., 1976: 237). Dengan demikian, sejak "klasifikasi Christian", "kosmologi" dimengerti sebagai sebuah cabang filsafat yang membicarakan asal mula dan susunan alam semesta; dan dibedakan dengan "ontologi" atau "metafisika umum" yang merupakan suatu telaah tentang watak-watak umum dari realitas natural dan supernatural; juga dibedakan dengan "filsafat alam" (The philosophy of nature) yang menyelidiki hukum-hukum dasar, proses dan klasifikasi objek-objek dalam alam (Runes, 1975: 68-69). Namun demikian, walau secara definitif "kosmologi" dibedakan dengan "ontologi" maupun "filsafat alam", pemilahan yang tegas dalam analisis konseptual antara ketiga bidang tersebut merupakan suatu usaha yang sulit dikerjakan, mengingat objek material dan objek formal yang hampir sama.

Selain dipakai dalam khasanah pemikiran filsafat, istilah "kosmologi" juga dipakai dalam lingkup ilmu empiris, yakni dikenali sebagai ilmu yang menggabungkan hasil-hasil pengamatan astronomis dengan teori-teori fisika dalam rangka menyusun hal-hal astronomis atau fisis dari alam semesta dalam suatu kesatuan dengan skala yang besar (Munitz, dalam: Edward, ed, 1976: 238). Kosmologi ilmiah (scientific cosmology) lebih berpijak pada suatu studi empiris tentang gejala-gejala astronomis. Upaya-upaya yang selalu dilakukan adalah membuat modelmodel "alam semesta" atas dasar penemuan-penemuan observatorial oleh para astronom. 
Dengan demikian sangat berbeda dengan "kosmologi filsafat" yang murni konsepsional dan merupakan analisis kategorial yang dilakukan secara "spekulatif" oleh para filsuf. Adapun kajian filosofis terhadap "kosmologi ilmiah" merupakan sub-bagian dari kajian "filsafat ilmu", dengan fokus telaah pada aspek-aspek metodologis dan epistemologis bangunan "kosmologi ilmiah" sebagai "ilmu". Kajian yang dilakukan dalam makalah ini adalah kajian kosmologi filsafat, sekalipun unsur-unsur pemikiran yang ditelaah terkait dengan kosmologi ilmiah tentang ruang-waktu, yang bagaimana pun terkait pula dengan gejala-gejala fisis dan astronomis.

Dalam tradisi pemikiran Barat (Yunani, Eropa), perkembangan pemikiran kosmologi filsafat berkembang sejalan dengan perkembangan pemikiran filsafat Barat. Tonggak perubahan dari perenungan tentang "kosmos" berpindah pada perenungan tentang "manusia", dimulai oleh kaum Sofis pada Abad ke 5 Sebelum Masehi (Hatta, 1964: 2). Dengan demikian, telah terjadi kembali "pembongkaran dunia" yang fundamental setelah sebelumnya manusia meninggalkan "dunia mitos" masuk ke dalam "dunia kosmos". Atas dasar interpretasi baru tentang "dunia" tersebut, para "dewa-dewi" yang masih mempunyai peranan dalam "dunia kosmos", secara fungsional perannya digantikan oleh anasir-anasir dan hukum-hukum kodrat "yang tidak berpribadi" (impersonal). "Dunia" kemudian diyakini sebagai suatu kesatuan unsur-unsur dasar yang memiliki kodrat dan hukum-hukum-nya sendiri. Memang tidak dapat dipungkiri bahwa pada awal perkembangannya kosmologi para filsuf alam tidak sepenuhnya dapat melepaskan diri dari pengaruh kosmogoni dan spekulasi eskatologis yang terdapat dalam mitologi Yunani (Burnet, 1953:1-4), dan kosmologi filsafat jelas bukan suatu mitologi, sekalipun kedua-duanya merupakan "usaha rasional" dari manusia untuk mencari penjelasan tentang berbagai hal mengenai "dunia”. Dalam tradisi filsafat Barat, mitologi lebih bersifat spekulatifdeduktif, sedangkan kosmologi filsafati cenderung lebih kritis-induktif dalam arti tidak mungkin lagi menutup mata terhadap kosmologi ilmiah maupun temuan-temuan ilmiah yang lain.

Topik utama kosmologi filsafat menurut Hegel adalah tentang "kontingensi" (kemestian yang merujuk pada "hukum"), "kepastian", "keabadian", batas-batas dan hukum formal dunia, kebebasan manusia, dan asal mula kejahatan. Namun rata-rata filsuf hanya mempersoalkan hakikat dan hubungan antara ruang dan waktu, dan persoalan tentang hakikat kebebasan dan asal mula kejahatan sebagai materi telaah di luar bidang kosmologi (Runes, ed, 1975: 69). Secara umum bangunan pemikiran kosmo-logi filsafat berpijak pada prinsip-prinsip ilmu ataupun dalil-dalil metafisis, sehingga pada satu sisi berkaitan dengan fakta-fakta empiris, pada sisi lain berhubungan dengan kebenaran metafisis tertentu. Dengan demikian dari pijakan ini mudah dilihat bahwa kosmologi filsafat memiliki nilai bila dia mampu memberi kerangka pemahaman terhadap peristiwa-peristiwa alami/kodrati, batas-batas dan "hukum" ruangwaktu "dunia", dan bagaimana "keterbatasan manusiawi" tersebut mampu "diatasi".

Secara historis perkembangan kosmologi filsafat (barat) dimulai dari filsuf-filsuf alam pra Sokratik, yang kemudian persoalan-persoalannya oleh Plato dalam "Timaeus" dan oleh Aristoteles dalam "Physics" disistematisir dan diperluas. Secara umum kosmologi filsafati di Yunani, dengan berbagai varian pemikiran, sepakat bahwa ruang jagad raya ini terbatas dan di 
bawah pengaruh hukum-hukum yang tidak dapat diubah, yang memiliki ketentuan dan irama tertentu. Perkembangan berikut, pada Abad Tengah, mulai diperkenalkan konsep-konsep "penciptaan" dan "kiamat", "keajaiban" dan "pemeliharaan" oleh Tuhan dalam kosmologi. Seirama dengan perkembangan ilmu empiris, kosmologi filsafat zaman modern sebagaimana dikemukakan oleh Descartes, Leibniz, maupun Newton mengalihkan kecenderungan yang muncul pada Abad tengah kepada corak pemikiran yang lebih dekat dengan pemikiran Yunani. Bahkan sejak Immanuel Kant, telaah kosmologi filsafati selalu dalam kaitan dengan isue-isue metafisika. Varian lain yang berkembang dan perlu disebut adalah kosmologi modern yang lebih "positif" sebagaimana dikemukakan oleh Pierce, yang menyatakan bahwa pokok soal yang harus dijawab oleh kosmologi adalah tiga hal, yakni, prinsip-prinsip tentang perubahan, hukum, dan kontingensi kosmis (Runes, 1975: 69). Varian "pengimbang" yang lain untuk pemikiran kontemporer adalah Whitehead, dengan "mengembalikan" kosmologi pada lingkup "hukum kodrat" yang lebih luas terkait dengan kebudayaan dan ilmu (Whitehead, 1960: 143).

Secara sistematis, kosmologi filsafat dibedakan dalam empat kelompok varian besar dengan dasar pengelompokan: (1) Berpijak dari keyakinan ontis bahwa hakikat dunia itu "jamak" ataukah "tunggal" (monisme, pluralisme). (2) Kedudukan manusia dalam kosmis (subjektivistis, objektivistis). (3) Esensi dan substansi manusia dengan esensi dan substansi dunia yang lain (penonjolan "perbedaan" antara esensi dan substansi manusia dengan esensi dan substansi dunia yang lain pada: Husserl, Scheler, Hartman, dan Heidegger; pengutamaan pada "kesamaan" antara esensi dan substansi "pengkosmos-pengkosmos" pada: panpsikisme dan Whitehead), dan (4) Pendekatan sintesis (Bergson, Theilard de Chardin, dan kosmologi Pancasila) (Bakker, 1995: 42-52). Klasifikasi yang dilakukan Bakker yang masih searah dengan kecenderungan kosmologi post-Kantian, yakni mengaitkan telaah kosmologi dengan "metafisika", membawa kajian kosmologi pada pendekatan integratif dengan bidang-bidang pokok filsafat yang lain, baik itu metafisika, epistemologi, aksiologi, maupun filsafat manusia. Terdapat dua konsekuensi yang meski diterima, bila pendekatan demikian yang dianut, yakni, pertama, kajian kosmologi filsafati menjadi kajian yang "arbriter", dalam arti varian-varian pandangan metafisis dan pendekatan (orientasi epistemologis) meski dipertimbangkan dalam suatu telaah yang "komprehensif" dan "dialogis", karena tanpa titik awal yang demikian yang terjadi adalah "penghakiman" atas suatu metafisika/ epistemologi oleh metafisika/epistemologi lain. Sebuah dimensi "meta-metodologi-filsafat" yang kurang disadari dalam telaah-telaah filsafat. Kedua, jangkar kajian pada "faktisitas-kedirian" dari "aku" (subjek eksistensial) sebagaimana muncul dalam pendekatan antropologi metafisis, membuka peluang untuk mengkaji kosmologi filsafat tidak hanya pada tingkat "tradisi besar para filsuf" namun juga berangkat dari "tradisi kecil" manusia "yang bukan filsuf" dengan kerangka pendekatan "sosioempiris". Dengan pendekatan "sosiologi (pengetahuan) filsafat", secara empiris bisa dilacak "jangkar-jangkar sosial" dari sesuatu yang sudah dianggap sebagai "suatu pandangan dunia" dari masyarakat tertentu, baik itu berkaitan dengan "pandangan dunia secara holistik", maupun aspek-aspek pemahaman tertentu dari "pandangan dunia" masyarakat tersebut. Dari "pandangan dunia" tersebut dapat dijabarkan pemahaman manusia tentang dunianya, yakni aspek kosmologi tentang waktu, terutama berkaitan dengan "keyakinan" (antropologis) orang tentang adanya pengaruh waktu (watak tahun, bulan, hari, dan jam) terhadap manusia. 
Secara sistematis, perspektif-perspektif kosmologi metafisis tentang "waktu", sebagaimana banyaknya varian pendekatan dalam kosmologi, secara garis besar dapat dipilah dalam empat kelompok, yakni: (1) Subjektivisme yang menyatakan bahwa waktu merupakan sesuatu yang tidak nyata, hanya bersifat subjektif-individual. Pemikiran yang demikian dianut oleh Parmenides, Zeno, Budhisme, Advaita Vedanta, Descartes, Leibniz, Locke, Hume, Berkeley, Fichte, Scheling, Hegel, Kant, Morris Schlick, Reichenbach, dan Carnap). (2) Realisme Ekstrem yang menyatakan bahwa waktu merupakan realitas absolut yang universal, tidak mempunyai kesatuan yang intrinsik dan hanya menunjukkan urutan-urutan murni. Kosmologi yang demikian dapat ditemukan pada kosmologi Indonesia/ Jawa, Jaina, Nyanya, Vaiseshika, Gassendi, Newton, Clarke, Whitehead, dan Alexander. (3) Realisme lunak, yang menyatakan bahwa waktu merupakan aspek perubahan yang nyata, sekalipun dihasilkan oleh subjek yang berabstraksi. Corak kosmologi yang demikian nampak pada pemikiran Aristoteles, Agustinus, Thomas Aquinas, Einstein, dan kosmologi Pancasila. Dan (4) Subjektivisme lunak yang menerima waktu sebagai suatu yang heterogen sebagaimana dikemukakan oleh Bergson, atau sebagai dimensi historis dari pribadi, sebagaimana diyakini oleh eksistensialisme (Bakker, 1995: 111-116). Dari "peta kosmologi" di atas, terlihat bahwa tradisi kosmologi timur paling dominan diwarnai oleh subjektivisme dan realisme ekstrim. Dari berbagai varian yang ada itu pula, kiranya dengan mudah dapat dilihat "konsekuensi-konsekuensi logis" dari suatu varian pemikiran kosmologis terhadap pandangan manusia tentang aspek-aspek lain dari kehidupannya.

\section{Pokok-pokok Kosmologi Hawking}

Sejauh batasan "kosmologi ilmiah" sebagai ilmu yang menggabungkan hasil-hasil pengamatan astronomis dengan teori-teori fisika dalam rangka menyusun hal-hal astronomis atau fisis alam semesta dalam suatu kesatuan dengan skala yang besar (Munitz, dalam: Edward,ed, 1976: 238) diterima, maka kosmologi Hawking kiranya termasuk "kosmologi ilmiah". Ciri-ciri kosmologi yang demikian nampak nyata sekali dalam karyanya yang paling terkenal "A Brief History of Time" (Riwayat Sang Kala). Dalam "kata pengantar" buku tersebut, Carl Sagan menyebut Hawking sebagai penerus yang berharga dari Newton (penjelajah jagad paling besar) dan Dirac (penjelajah jagad paling kecil), di samping buku "A Brief History of Time" dinilai pula sebagai buku yang mampu mengungkap garis depan fisika, astronomi dan kosmologi (Hawking, 1995a: xvi). Pokok-pokok kosmologi Hawking yang diuraikan berikut ini terutama didasarkan pada buku tersebut, di samping kumpulan risalah ceramah dan wawancara Hawking yang terbit lebih kemudian, yakni "Black Holes and Baby Universe and Other Essays" (1993).

Medan jelajah Hawking adalah "fisika teoritis" (Hawking, 1995a: xii), yakni sebuah studi yang berupaya untuk mencari "self-consistency" yang rasional dan lebih menitik beratkan usaha pada pengembangan (teoritis) dari pada pembuktian melalui eksperimen (Hawking, 1995b: 4l). Dalam wilayah jelajah yang demikianlah Hawking hendak menjawab beberapa pokok persoalan, misalnya: Seperti apakah awal jagad raya, bila awal dan akhir itu ada? Apakah pada kondisi awal dan akhir jagad raya tetap berlaku hukum-hukum fisika yang sama? Model 
yang bagaimanakah dari pemahaman kita tentang awal dan akhir jagad raya yang memungkinkan berlakunya hukum-hukum fisika (Teori umum relativitas dan Mekanika kuantum) tanpa mengingkari hasil-hasil pengamatan astronomis ? Bagaimana konsep ruangwaktu yang memadai bagi suatu model awal dan akhir jagad raya? Apakah segala peristiwa dalam Jagad raya memang tunduk pada hukum-hukum sains tertentu? Kalau ada hukum sains yang demikian, bagaimana dengan persoalan kebebasan dan tanggungjawab?

Kosmologi Hawking secara "sederhana" pada pokoknya hendak menjawab persoalan tentang struktur dan "arah" perkembangan realitas kosmis dengan "menggabungkan" dua pendekatan, yakni pendekatan makrokosmos teorigravitasi yang diwakilioleh Teori Relativitas Umum (TUR) dengan pendekatan mikrokosmos Teori Mekanika Kuantum (TMK) yang diwakili oleh asas ketidakpastian Heisenberg. TUR membawa telaah pada suatu hipotesa adanya awal jagad raya itu berupa dentuman besar (singularitas), sedangkan TMK (klasik) membawa pada hipotesa tentang "peluruhan jagad raya" (kerkahan besar) (Hawking, 1995a: 125). Kedua hipotesa tersebut sesuai dengan hasil pengamatan tentang "pemuaian jagad raya" dan "lubang hitam" (perapatan jagad raya). Persoalan yang mesti dijawab adalah: Bagaimana dua teori yang "saling bertentang" tersebut diterima kedua-duanya, mengingat keduanya didukung oleh data-data observatoral?

Atas dasar teorema yang dikembangkan Penrose bahwa setiap benda langit yang runtuh karena gravitasi pada akhirnya harus membentuk suatu singularitas; dan dipadu dengan model pemuaian jagad raya Friedmann, Hawking "menemukan" bahwa bila arah waktu dibalik maka teorema Penrose menghasilkan model pemuaian jagad raya yang dibalik, yakni menyusut. Baik pemuaian maupun penyusutan tersebut diawali dan diakhiri oleh suatu "singularitas" (Hawking, 1995a: 57-58). "Penemuan" ini memiliki kedudukan penting dalam konsep Hawking tentang ruang-waktu dan awal-akhirjagad raya.

Teori yang dikembangkan dalam rangka memberi penjelasan tentang "penggabungan" TUR dan TMK dinamainya Teori Gravitasi Kuantum (TGK), walau diakuinya bahwa teori yang lengkap belum terbangun (Hawking, 1995b: 91). TGK menjelaskan bahwa pada dua momen tersebut (dentuman besar dan lubang hitam) diasumsikan timbul medan gravitasi yang sangat besar oleh adanya rapatan tak terhingga. Dalam keadaan yang demikian berlaku hukum ketidakpastian Heisenberg, yakni pada "singularitas" demikian tingkat ketidakpastiannya semakin tinggi karena posisi maupun kecepatan sebuah partikel tidak bisa diukur dengan ketelitian yang sama tinggi (Hawking, 1995b:128). Dari titik pijak ini, ruangwaktu tidak bisa lagi dipahami sebagai "sejarah tunggal" yang linear, melainkan "berbagai kemungkinan yang telah berkembang menjadi sejumlah sejarah yang berbeda-beda”. Semua itu tergabung dalam sebuah kelompok sejarah yang mungkin untuk jagad raya (Hawking, 1995b: 128).

Pada massa nol dan setara dengan pemuaian jagad raya terjadi penurunan suhu dan gravitasi sampai pada titik kritis (konstan tertentu). Setelah melampaui ambang kritis, terjadi penyusutan jagad raya. Penyusutan ini dibarengi dengan meningkatnya tingkat rapatan yang tingkat kerapatannya berbanding lurus dengan peningkatan gravitasi menuju pada kerapatan 
go

al

kn dao

$\sigma, \quad 57$

d

rnam

ml

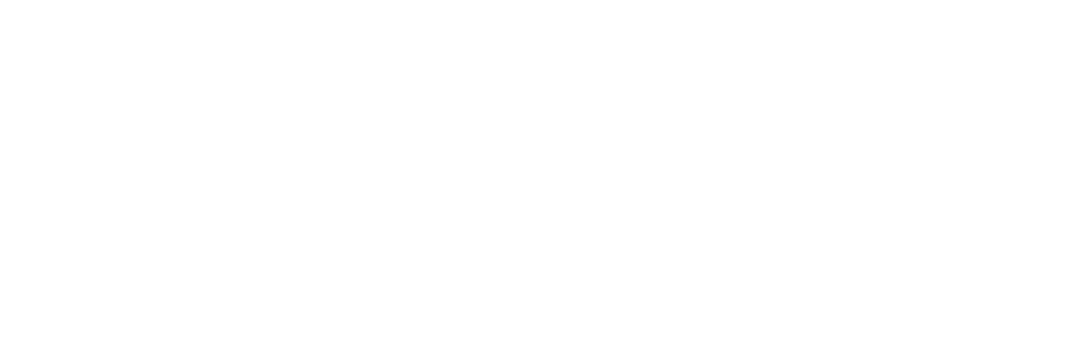

A

g

D $\quad \mathrm{kl}$

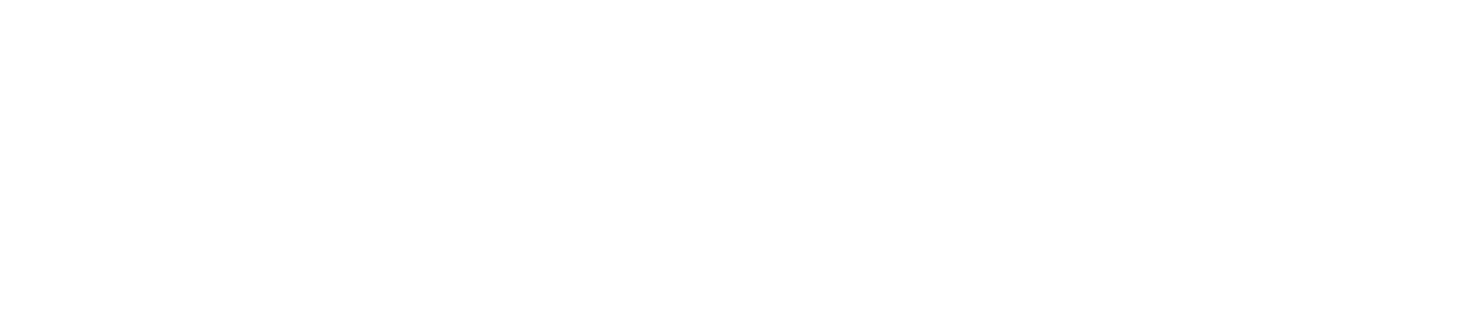

F 2

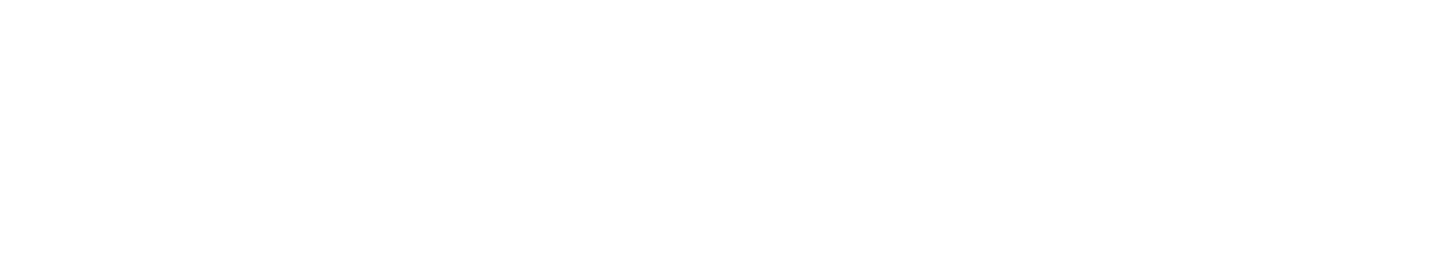

mı

6

$\mathrm{mn}$

D Praangg an $\mathrm{M}$ af $-\mathrm{e} \quad \mathrm{K}$ m $\mathrm{H}$

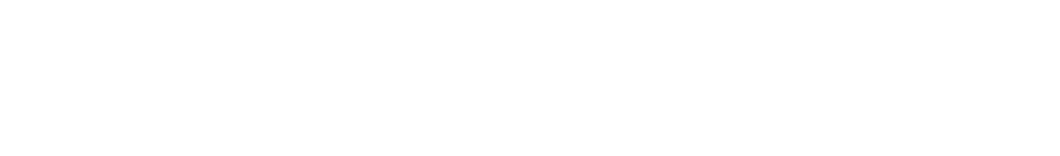


kontemporer kebanyakan tidak memiliki latar belakang matematika yang memadai untuk menyejajarkan diri dengan perkembangan modern fisika teoritis. Sekalipun ada filsuf sains, kebanyakan mereka merupakan ilmuwan-ilmuwan yang tersisih karena tidak mampumembuat penemuan-penemuan baru dalam bidang fisika teoritis, lalu beralih ke penulisan filsafat fisika (Hawking, 1995b: 41). Hawking secara sinis membalas predikat yang diberikan para filsuf kepadanya, seperti: nominalis, instrumentalis, positivis, realis dengan menyatakan bahwa kemajuan fisika teoritis tidak ditentukan oleh kategori-kategori yang diciptakan oleh filsuf maupun ahli sejarah sains, melainkan usaha pemusatan nalar untuk mencari "self-consistency" dalam rangka pengembangan teori fisika, yang darinya dapat dibuat prakiraan-prakiraan yang kemudian dapat diuji dengan pengamatan (Hawking, 1995b: 41). Bagi Hawking, jika hasil pengamatan sesuai dengan prakiraan, itu bukan membuktikan kebenaran teori, melainkan hanya memperpanjang kelayakannya untuk membuat prakiraan-prakiraan lebih lanjut yang kelak akan diuji coba pula melalui pengamatan (Hawking, 1995b: 42).

Dari posisi yang diambilnya Hawking mengakui bahwa dia adalah seorang realis dalam arti percaya adanya jagad raya secara objektif ada di luar sana untuk diselidiki dan dipahami, dan sama sekali bukan solipsis yang hanya bermain-main dengan angan-angan sendiri. Secara epistemologis, suatu teori fisika hanyalah sebuah model matematik yang digunakan untuk menjabarkan hasil-hasil pengamatan. Sebuah teori dinyatakan baik bila model yang dihasilkannya bisa diandalkan, bila mampu menjelaskan sejumlah pengamatan, dan jika mampu pula memprakirakan hasil-hasil pengamatan baru (Hawking, 1995b: 43). Posisi yang diambil Hawking serupa dengan posisi fallibisme Popper, walau "koraborasi bukti" Popper lebih pada rumusan negatif, yakni bahwa suatu teori akan semakin kuat bila usaha-usaha untuk menyanggahnya mengalami kegagalan (Popper, 1963: 36). Hawking sendiri mengaku sulit untuk menjadi seorang realis, sementara yang dianggap realitas dikondisikan oleh "teori" yang diyakini. Namun Hawking tetap berpegang bahwa positivisme yang diambilnya merupakan satu-satunya "isme" yang mungkin bagi seseorang bila ia ingin menemukan hukum-hukum baru dan cara-cara baru untuk menjelaskan jagad raya (Hawking, 1995b: 44). Dengan demikian Hawking menolak metafisika yang mendasari fisika klasik yang memahami realitas sebagai sebuah "sejarah tunggal tertentu". Metafisika yang demikian tidak lagi sesuai dengan prinsip dasar mekanika kuantum yang membuka realitas pada berbagai "kemungkinan sejarah". Dalam teori kuantum tidak timbul masalah dengan "kucing Schrodinger" (McEvoy, 1997: 146-147), karena dua kemungkinan dapat muncul secara bersama-sama, karena dua fungsi gelombang menjadi satu (Hawking, 1995b: 45).

\section{E. Refleksi Kritis atas Kosmologi Hawking}

Sejauh teori kosmologi ilmiah Hawking diletakkan dalam kerangka "filsafat ilmu", persoalan yang muncul lebih terkait dengan "issue-issue epistemologis" yang berkaitan dengan "hukum sains" dan "status epistemologis teori" (Hunnex, 1970:5). Pada issue pertama, muncul persoalan "loncatan logis" bagaimana suatu generalisasi deskriptif dapat memiliki nilai peramalan. Pada issue kedua, muncul persoalan bagaimana pernyataan umum tentang entitas 
yang tidak dapat diamati, seperti halnya "partikel terkecil" dapat diteguhkan. Sejauh mana eksplanasi teori sungguh-sungguh memberikan "realitas yang sesungguhnya"? Bila lingkup fisika teoritis adalah "self-consistency", sejauh mana testabilitasnya dapat diukur, terlebih bila "perangkat pengamatan" ataupun "eksperimen" untuk menyanggahnya atau pun meneguhkannya belum ada? Pernyataan Hawking bahwa jagad raya mandiri (self-contained) dan secara deterministis diatur oleh hukum-hukum sains (Hawking, 1995b: 85), sesungguhnya telah melampaui bukti-bukti observatoral yang sangat terbatas, yang tidak mengizinkan "over estimate" semacam itu. Bila bukti bukan penentu dalam fisika teoritis, sejauh mana "teori" yang dihasilkannya tidak jatuh dalam "fiksi" atau "pseudo ilmiah" belaka? Secara metafisis tetap bisa dipertanyakan sejauh mana suatu "model matematis" mampu mewakili "realitas fisis".

Dari segi antropologi metafisis, konsep proses jagad raya dan konsep ruang-waktu Hawking tidak banyak membantu menjawab tentang "hakikat eksistensi manusia", karena berangkat dari kerangka teoritis yang mengandaikan eksistensi manusia di jagad raya muncul dari hukum ketidakpastian yang menyertai proses terbentuk dan hancurnya jagad raya. Juga, apapun "konsep manusia" maupun "kemajuan peradaban manusia" tidak banyak artinya bagi "jagad raya", dalam arti manusia tidak akan mampu "mempengaruhi" atau pun "menghentikan" proses pemuaian jagad raya yang oleh Hawking dihipotesakan sedang mendekati titik kritis sebelum hancur dalam proses penyusutan.

Secara epistemologis, seluruh kerangka teori Hawking pada dasarnya "hanya" merupakan rangkaian hipotesis, atau istilah Hawking sendiri: "model", yang berpijak "di atas buih-buih hipotesa/teorema yang lain". Gelombang gravitasi yang menduduki peran sentral dalam teori kuantum-gravitas, dapat diketahui ada-tidaknya tiga tahun lagi (Kompas, 16 Nopember 1997). Dan bila pun gelombang gravitasi itu memang nanti terbukti ada, masih banyak postulat/ hipotesa/pengandaian lain yang menunggu bukti-bukti observatoral.

Persoalan yang muncul dengan penerimaan terhadap fisika modern adalah "pemahaman baru" bahwa realitas fisis direduksi sebagai "energi". Tidak ada energi maka tidak ada massa. Tidak ada massa maka tidak ada ruang. Tidak ada ruang maka tidak ada waktu (Hunnex, 1970: 16)

\section{F. Penutup}

Dari "uraian singkat" di atas kiranya bisa ditarik kesimpulan kecil bahwa Hawking ternyata tidak mampu keluar dari praanggapan metafisis-epistemologis yang telah mentradisi dalam ilmu fisika, yakni tradisi "positivistis'. Tradisi "positivistis" bagaimanapun harus diakui perannya dalam membangun "dunia fisik", sebagaimana ditunjukkan oleh perkembangan ilmu alamiah dan teknologi. Namun bagaimanapun, sebagaimana penerimaan Hawking atas asas ketidakpastian Heisenberg, sejauh manapun fisika mengalami kemajuan, sulit kiranya untuk menjadi perangkat "peramalan"-determisnistik bagi proses-proses yang lebih rumit 
sebagaimana ada dalam "otak manusia". Pada sisi inilah justru Hawking menunjukkan "kebesarannya", bahwa semaju apapun ilmu fisika atau pun kosmologi ilmiah, ia tetap tidak akan mampu menjawab pertanyaan "untuk apa manusia ada".

Daftar Pustaka

Bakker, A., 1995, Kosmologi Dan Ekologi, Filsafat Tentang Kosmos Sebagai Rumah tangga Manusia, Penerbit Kanisius, Yogyakarta.

Burnet, J., 1953, Greek Philosophy, Thales to Plato, Macmillan \& Co, London.

Edward, Paul, ed, 1976, The Encyclopedia of Philosophy, The Macmillan Co. and Free Press, New York

Ferguson, Kitty, 1995, Stephen Hawking, Pencarian Teori Segala Hal, (asli: Stephen Hawking: Quest for a Theory of Universe, alih bahasa: Handyana Pudjaatmaka), Puataka Utama Grafiti,Jakarta

Hatta, M., 1964, Alam Pikiran Yunani, jilid II, Tinta Mas, Jakarta.

Hawking, Stephen, 1995a, Riwayat Sang Kala, Dari dentuman besar hingga lubang hitam (Asli: A Brief History of Time, alih bahasa: Handyana Pudjaatmaka), Puataka Utama Grafiti,Jakarta

Hawking, Stephen, 1995b, Black Holes and Baby Universe, Lubang Hitam dan Jagad Bayi dan esai-esai lain, Penerbit PT Gramedia Pustaka Utama, Jakarta

Hunnex, 1970, Chronological and Thematic Charts of Philosophies and Philosophers, Academie Books, Michigan

McEvoy, JP., Zarate, Oscar, 1997, Mengenal Teori Kuantum, for beginners, Mizan, Bandung

Pitzer, Bill, \& Holland, Earle, "Bagaimana menagkap gelombang gravitasi?" Kompas 16 Nopember 1997, Jakarta

Popper, Karl, R., 1963, Conjectures and Refutations: The growth of scientific knowledge, Harper Torchbook, New York

Rescher, Nicholas, 1984, The Limits of Science, University of California Press, Berkeley

Runnes, D.D., 1975, Dictionary of Philosophy, Littlefield, Adam \& Co., New Jersey.

Ziman, John, FRS, 1984, An Introduction to Science Studies, The Philosophical and social aspects of science and technology, Cambridge University Press, Cambridge

Whitehead, 1976, The Adventure of Ideas, Mentor Book, New York. 